\title{
Arvo on teonsana
}

Kuten Juhani Pietarisen kommenttikirjoituksesta käy ilmi, olen hänen kanssaan samaa mieltä tärkeästä seikasta: ihmiset joutuvat elämänsä kulussa tekemään valintoja toisensa poissulkevien vaihtoehtojen välillä. Monet valinnat vaikuttavat ratkaisevasti myös kulttuurin ulkopuoliseen luontoon. Olen kuitenkin hänen kanssaan eri mieltä erittäin tärkeästä seikasta: en usko, että käsite "arvo" on kelvollinen luonnehtimaan tällaisten valintojen perustaa. Vaikka Pietarinen kuinka sen kieltää, käsite "arvo" implikoi, että eri vaihtoehdoille on löydettävissä yhtenäinen vertailuperusta. Kuten hän itse kommenttinsa lopussa kirjoittaa: "... on pakko suorittaa eri asioiden vertailua, ja siihen tarvitaan arvoja". Toisin sanoen, "arvot" luovat Pietarisen mielestä perustan, jonka nojalla erilaisten asioiden erilaisia merkityksiä voidaan verrata toisiinsa. Tulkintakykyni ei riitä antamaan Pietarisen lausumalle muuta sisältöä.

Käsitykseni on, että kaikille ihmiselämässä eteen tuleville vaihtoehdoille ei ole yhtenäistä vertailuperustaa. Yhtenäisen perustan puuttumisesta nimenomaan seuraa valintojen traagisuus: ei ole mahdollista loppuun asti tietää, mitä eri vaihtoehdot todella tärkeissä valintatilanteissa merkitsevät. Rajatuissa tilanteissa vertaaminen on tietenkin mahdollista. Markkinoilla muodostuvat hinnat auttavat arvioimaan monenlaisten tavaroiden keskinäistä vaihdettavuutta. On luonnollista, että hinta ja arvo kietoutuvat käsitehistoriallisesti toisiinsa. Niiden keski- näisen yhteyden havaitseminen auttaa hälventämään arvon käsitteen epäselvyyttä. Esimerkiksi arkikielen sanonta "(se-ja-se) ei ole vaivan arvoista" osoittaa käsitteiden yhteyden: (sen-ja-sen) tekemisen "arvo" arvioidaan tekemisestä aiheutuvan vaivan eli kustannusten eli hinnan nojalla.

Näkemyksiemme ero tulee varsinaisesti ilmi korvaamattomien asioiden kohdalla. Korvaamattomia asioita ei voi arvioida sellaisten käsitteiden avulla, joiden perustana on vaihdettavuus. Korvaamattomilla asioilla ei siis ole hintaa tai arvoa. (Eino Kaila, Syvähenkinen elämä, s. 54, kääntää paradoksin toisin päin pannessaan tukkukauppias Agathonin ihmettelemään, että "aineelliset arvot keskimäärin ovat rahassa laskien tavattomasti paljon kalliimpaa tavaraa kuin henkiset arvot").

Käsitteiden merkitys ja mieli on auttaa tekemään sellaisia erotteluja, jotka ovat inhimillisessä elämässä välttämättömiä. Keskeinen ero vallitsee korvaamattomien ja vaihdettavien asioiden välillä. Käsitteellä "arvo" eroa ei ole mahdollista tehdä, kuten totesin jo alkuperäisessä kirjaarvostelussani. Pietarinen ei ole toteamusta edes huomannut lukiessaan arvostelua arvofilosofiansa silmälasien läpi. Puheenparret, joilla termi "arvo" sidotaan korvaamattomiin asioihin, ovat harhaanjohtavaa höpinää. Korvaamattomia asioita ei verrata muihin, niitä kunnioitetaan ja vaalitaan elämän perustana.

Inhimilliset elämäntilanteet ovat ainutkertaisia ja siis kun- kin ihmisen omasta näkökulmasta käsin korvaamattomia. Luonnon elinvoima on ihmiselämän korvaamaton perusta. Haasteemme on tehdä selväksi, mitä ihmiselämän tiettyjen tekijöiden korvaamattomuus tarkoittaa yhteiskunnallisesti ja poliittisesti. Vaikeita yhteiskunnallisia ristiriitoja syntyy nimenomaan silloin, kun vastakkain on inhimillisiä elämänkäytäntöjä, joita ei voi vaihtaa keskenään. Esimerkiksi Muotkatunturin hakkuukiistassa on vastakkain kaksi erilaista näkemystä siitä, miten metsä nivoutuu osaksi suomalaisen yhteiskunnan elämänkäytäntöjä: muotoutuuko Muotkatunturin metsä modernin metsätalouden vai porotalouden ehtojen mukaiseksi? Valinta on poliittinen. Sen taustana on kuitenkin räikeän epäsymmetrinen valta-asetelma Metsähallitus on julkisen vallan instituutio, joka edustaa, toteuttaa ja muovaa yhteiskunnassa vallitsevaa näkemystä metsän asemasta yhteiskunnan elämänkäytännöissä. Asemansa nojalla metsähallitus käyttää toimissaan poliittista valtaa. Poromiehet sen sijaan edustavat omaa itseään.

Asetelman poliittinen ydin on siis seuraava: Onko suomalaisessa yhteiskunnassa tilaa Muotkatunturin poromiesten elämänkäytännöille? Mikäli on, metsät on säilytettävä sellaisina, että elämäntapa on myös käytännössä mahdollinen. - Miksi metsähallituksen ja poromiesten "erilaisten arvojen" tunnistaminen, vertaaminen ja yhteensovittaminen ei voi johtaa samaan lopputulokseen? Koska arvojen yhteensovit- 
taminen hävittää näköpiiristä poliittisen valinnan ja sen taustana olevan valta-asetelman.

Tieto on tämäntapaisten ristiriitojen yhteydessä arvokasta ainakin kahdella tapaa. Luonnontieteen nojalla voidaan arvioida, kuinka ehdottomasti elämänkäytännöt ovat keskenään ristiriitaisia, eli onko sittenkin mahdollista harjoittaa Muotkatunturilla samanaikaisesti metsätaloutta ja porotaloutta. Luonnontiede auttaa lisäksi arvioimaan, mikä kussakin valintatilanteessa on luonnon elinvoiman kannalta korvaamatonta. Yhteiskuntatieteellis-historiallisen tiedon ja näkemyksen nojalla voidaan arvioida, onko mahdollista korvata jommankumman osapuolen kannalta kieltei- nen päätös ilman, että kyseisen osapuolen koko olemassaolo vaarantuu. Häviääkö poroelinkeino, jos Muotkatunturin metsät hakataan? Loppuuko metsätalous, jos Muotkatunturin metsät suojellaan? Ekologinen ja historiallis-yhteiskunnallinen tieto eivät poista poliittisen valinnan välttämättömyyttä. Sen sijaan tieto auttaa selkiyttämään, mitkä tietyn valintatilanteen varsinaiset vaihtoehdot ovat.

Poliittinen haaste - julkisen vallan vastuu, jos niin halutaan sanoa - on lisätä ihmisten mahdollisuuksia vaalia niitä asioita, jotka heille ovat korvaamattomia. Ihmisten on voitava tehdä valintoja oman päänsä mukaan. Ihmisten on voitava myös luottaa siihen, että valinnan mahdollisuudet ovat todellisia. Juuri luottamusta on kuitenkin poliittisista syistä usein vaikea saavuttaa. Vaikeuksia aiheuttavat muun muassa julkista valtaa edustavien instituutioiden toimintatavat. Lapin poromiesten on esimerkiksi pitkän kokemuksen nojalla vaikea luottaa siihen, että metsähallitus on poronhoidon suhteen vakavissaan, liittipä se periaatejulistuksiinsa millaisia arvolausumia tahansa. Vahvempi osapuoli on vastuussa luottamuksen synnystä, ja vain käytännön toimet luovat luottamukselle perustaa. Teot ratkaisevat.

Yrjö Haila 